\title{
Research Opportunities in Service Process Design
}

\author{
Arthur V. Hill* \\ Curtis L. Carlson School of Management, University of Minnesota, 321 19th Avenue South, Room 1/150, \\ Minneapolis, MN 55455-0413, USA \\ David A. Collier \\ Fisher College of Business, The Ohio State University, 2100 Neil Avenue, Columbus, OH 43210, USA \\ Craig M. Froehle \\ College of Business, University of Cincinnati, Cincinnati, OH 45221-0130, USA \\ John C. Goodale \\ College of Business, Ball State University, Muncie, IN 47306, USA \\ Richard D. Metters \\ Goizueta School of Business, Emory University, 1300 Clifton Road, Atlanta, GA 30322-2710, USA \\ Rohit Verma \\ David Eccles School of Business, University of Utah, Salt Lake City, UT 84112, USA
}

This paper presents an overview of the new issues and research opportunities related to four service operations design topics - the design of retail and e-tail service processes, design of service processes involving waiting lines and workforce staffing, service design for manufacturing, and re-engineering service processes. All four topics are motivated by new technologies (particularly web-based technologies) and require a multi-disciplinary approach to research. For each topic, the paper presents an overview of the topic, the relevant frameworks, and a discussion of the research opportunities.

\section{Introduction}

This paper challenges operations management scholars to devote energy to four service design topics, retail and e-tail service processes, call center workforce staffing, service design for manufacturing, and service process re-engineering. For each topic, the paper presents frameworks, reviews the relevant research, and suggests a number of questions for future research. Fundamentally, the increased interest in these research topics is driven by new technologies. Scholarly and managerial interest in e-tailing is driven by the explosion of Internet 
technologies, which will continue to change how service providers interact with customers. Research on workforce scheduling is motivated by the marked increase in the number, variety, and importance of call centers and multi-channel contact centers (including help lines, reservation centers, dispatch centers, etc.). Research in service design for manufacturing is similarly stimulated by new technologies and the rapidly evolving nature of relationships up and down the supply chain. Lastly, research in re-engineering is motivated by the need to implement these and other service design concepts in a world accelerated by technological change.

A major theme of this paper is that service design research is intrinsically multidisciplinary, drawing on operations, marketing, human resources, information technology, and other disciplines (Fitzsimmons and Fitzsimmons, 1999, 2001). This paper, therefore, addresses each of the four service process design topics from a multi-disciplinary point of view. For each of these four topics, the paper presents a framework and a number of questions for future research.

\section{Design of Retail and E-tail Service Processes}

Retail operations, and their on-line sibling, "e-tail" operations, are among the most important, dynamic, and difficult operations to manage. Retail service execution quality has been studied as an operational issue (e.g. Roth and Jackson, 1995; Soteriou and Zenios, 1999), a marketing issue (e.g. Parasuraman et al., 1988), and an operations strategy issue (e.g. Verma and Boyer, 2000). Retail-oriented operations management research has focused on a variety of issues, including forecasting techniques, the use of vendor-managed inventory (VMI), and the operational antecedents of service quality and profitability (especially in financial and banking services). Marketing research focusing on service design has made contributions principally in the area of service quality, both subjective and objective, and how gaps in service quality can affect customer satisfaction. The strategy literature has contributed to our understanding of retail services primarily through being integrated into both operations and marketing literature (see above references for examples). The multi-disciplinary nature of this research space makes it both a challenge and an opportunity.

One of the most critical objectives for this type of service operation is customer accessibility (Roth et al., 1997) and interaction. As technology continues to expand both the number and variety of customer touch-points and service delivery channels, researchers must continue to examine the important, and sometimes contentious, trade-offs between product/ channel variety and cost-effectiveness, as well as the consequences of automation, in retail service settings. Designers of service processes, especially in retail contexts, must consider the impact on efficiency (internal) as well as the impact on the customer (external) if better decisions are to be made (Chase, 1978).

Considering the operational, organizational and technology issues associated with developing new services (Froehle et al., 2000), the design of retail and e-tail service operations 
is a challenging issue for researchers and practitioners alike. Few, if any, structured frameworks have been offered specifically for retail/e-tail operations. The next section briefly describes some frameworks and research questions that may be useful to those pursuing research in this emerging area.

\section{Frameworks for Retail/E-tail Service Process Design}

Theory formulation in this area will have to contend with the fundamental differences between the retail and e-tail environments. Obviously, the front offices of retailers and e-tailers are radically different. Most studies have focused on this difference as well as the inherent marketing and pricing differences (e.g. Hoffman and Novak, 2000; Brynjolfsson and Smith, 2000). However, there are significant operational differences in the back-office as well. These differences stem from the differences between the "traditional" and the "digital" distribution strategies shown in Fig. 1. Traditional retailers often have an arborescent distribution strategy with truckloads proceeding from central warehouses to regional facilities, then regional facilities sending palette loads to retail outlets. The prototypical catalog/e-tailer digital distribution strategy has central facilities that send products directly to customers. The cost of shipping full truckloads of goods to a few hundred retail stores is trivial compared to the cost of shipping individual orders to millions of customer addresses. In summary, e-tailing has substantial advantages in inventory, facility, and labor costs at the expense of higher distribution costs.

The potential inventory savings in e-tailing is a good example of the "square root law." The total system safety stock with $N$ stores, independent and identically distributed demand, and common safety factors $k$, is $k \sigma N$ units. If the $N$ stores are replaced with a single warehouse linked to a web site, only $k \sigma \sqrt{N}$ units of safety stock are necessary (Evers, 1995). For example, if the number of stocking points is reduced from 4 to 1 , only half as much safety stock inventory is needed-and substantial overhead will be eliminated.

Central warehouses

\section{Regional warehouses}

\section{Retail outlets}

Customers

\section{Traditional System}

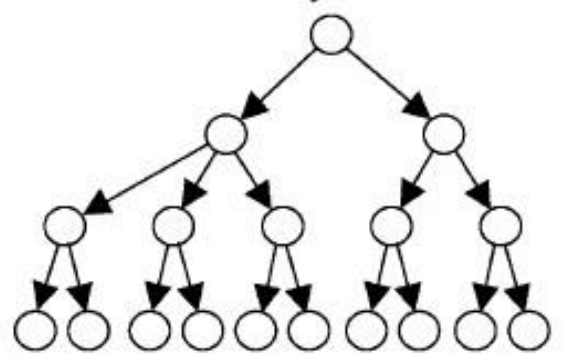

Digital System

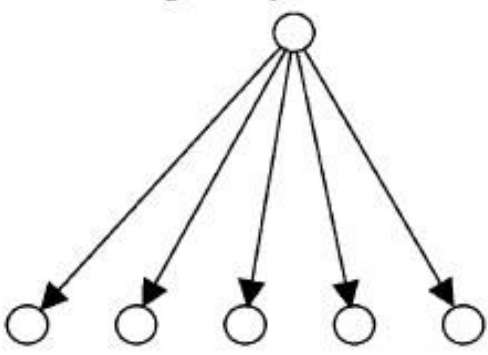

Fig. 1 Traditional vs. digital distribution strategies, traditional system, digital system, central warehouses, regional warehouses, retail outlets, customers.

Further, maintaining inventory record accuracy is a persistent problem for retailers (Fisher et al., 2000), and retailers hold more inventory due to the uncertainty of the actual inventory position. The problems can be extreme, with one "very successful retailer... (that is) a 
leader in information systems" (Raman, 2000, p. 100) finding that store inventory records are inaccurate on $71 \%$ of their products. This inventory inaccuracy also leads to the problem of "phantom stockouts," where goods may be in the store, but due primarily to customer reshelving, those goods cannot be found. One bookstore chain found that $19 \%$ of their stockouts were of this phantom type (Raman, 2000). Inventory accuracy is far less of an issue with a single facility that does not need to accommodate the physical presence of customers.

It would seem clear that a pure e-tailer would choose the digital strategy and a pure retailer would choose a traditional system. However, the combined e-tailer/retailer (click and brick) appears to be emerging as the dominant business model. The inherent difficulty for the e-tailing retailer back-office is that these two systems cannot be integrated easily. Differing aisle widths, aisle heights, forklift use, packing materials, and reverse logistics preclude combining pick-and-pack operations with those that focus on delivering palette-loads of goods.

In response, firms are applying several different strategies, with no single strategy emerging as dominant. Some firms, such as J.C. Penney, have entirely segregated corporate divisions, with the retail side and the catalog/e-tail side having entirely separate warehouse systems. The drawbacks of this solution are the excess inventories related to operating segregated systems and excess distribution costs. Approximately $60 \%$ of J.C. Penney's Internet customers pick up goods ordered on-line at a J.C. Penney owned store rather than have them delivered to their home. Yet, those goods are still shipped from the Internet division warehouse rather than being pulled from the shelves of the store that hands over the product. Many other firms, such as Wal-Mart, Macy's, and Bloomingdale's, have taken this segregation strategy a step further and have outsourced all their Internet orders to third party firms.

Another strategy that attempts to integrate back-office systems could be called the "professional shopper" strategy. Andersen Consulting reports that six retailers have adopted this strategy (Andersen Consulting, 2000). Here, when an Internet order is placed, a store employee walks the aisles of a retail outlet and picks the order. The downside of this strategy is the cost. Internet orders are doomed to be priced at retail plus shipping and handling. It also deprives firms of the basic inventory and personnel benefits of the digital model.

\section{Research Question for Retail/E-tail Service Process Design}

\section{Operational trade-offs}

Are generic models of operational trade-offs or competitive capabilities such as competitive progression theory by Roth (1996) or Ferdows and De Meyer (1990) sand-cone model, equally applicable to both off-line and on-line services?

\section{$\underline{\text { Strategic Advantage }}$}

Can we develop a taxonomy of e-tail strategic archetypes? Is there an archetype that generally performs better in practice? What operational issues contribute most significantly to this performance advantage? 


\section{Front-office/Back-office}

The line between front- and back-office continues to be blurred, with on- and off-line activities becoming more integrated in some situations and more de-coupled in others (Metters and Vargas, 2000). How does this influence the structure of the service process?

\section{Information Use in the Supply Chain}

As more retail commerce happens through technology-mediated means, our information level increases. What pieces of information are most useful in managing the supply chain? How can we assemble these transactional data, or combine them with other inputs, in order to create more accurate forecasting methods?

\section{Efficiency versus Personalization}

Is there an inherent trade-off between automation (technology applied for efficiency) and personalization, or can pursuing these two objectives be mutually reinforcing? How can technology be integrated into the service process in order to improve both efficiency and personalization?

\section{Operational Metrics}

Should retail operations have different performance metrics than e-tail operations? If so, what metrics are the most useful in each setting?

\section{Off-line/On-line Mix}

Is there an optimal mix of off- and on-line channels? What service elements are better handled off-line versus on-line? What operational parameters are necessary in order to begin to address these questions?

\section{Customer-introduced Variation}

Since the e-tail experience is heavily scripted by virtue of the technology by which it is delivered, does this mean e-tail processes are subject to less customer-introduced variation? What are the implications of this reduced variance on the design and delivery costs-as well as the benefits?

\section{Inventory and Logistics}

How much of the theoretical inventory benefits for e-tailers actually be achieved? How can the inherent logistical disadvantages be minimized? How do firms that are combined retailers and e-tailers manage their multiple layers of inventory and their incompatible logistics structures?

\section{Customer Service}


What implications are there for delivering retail or e-tail customer service over the Internet? How do computer-based communications media differ from more established media (e.g. telephone, face-to-face, etc.)?

\section{Waiting Line and Workforce Staffing Issues in Service Design}

Managing waiting lines for call centers and other service systems is a growing concern for many firms. Driven by new technologies such as the Internet, the number of call centers in North America has increased dramatically to meet the needs of e-tailing help lines, technical help lines, reservation centers, and field service dispatching. Call center revenues in the US is expected to increase by 250\% between 2000 and 2004 (Call Center Magazine, 2001).

The match between service demand and capacity has a substantial impact on profitability because of waiting time-effects on demand (Andrews and Parsons, 1989) and surplus capacity-effects on operating margins (Thompson, 1998). It is important to meet customer expectations early in the service delivery process so that negative first impressions do not affect perceived service quality later (Maister, 1985). Davis and Maggard (1990) found that waiting time prior to placing an order at a fast food restaurant was the most important factor in customer satisfaction when examining the waiting times in multistage processes. Thus, the multi-disciplinary approach advocated in this paper suggests that service design research should consider the information needs of managers related to waiting lines (the operations view) and customer satisfaction (dissatisfaction) with waiting times (the marketing view). Roth and van der Velde (1991) Competitive Service Strategy paradigm links operations to marketing where critical success factors connect service operations capabilities to target markets.

The linking variable between the operations and marketing views of waiting lines is the objective of adding value (Heskett et al., 1994). A few papers address how to value customer waiting time when service capacity is variable, and provide an indication of possible resources for capacity planning and scheduling information. For example, L.L. Bean (Andrews and Parsons, 1989) calculated the expected lost net profit from telephone orders due to customers waiting. Similarly, Ittig (1994) determined the number of clerks needed in a retail store by balancing the cost of additional servers against the increased revenue from increased demand due to lower expected waiting time. Davis (1991) proposed a method of valuing waiting time in a fast food restaurant that used a distribution of the opportunity cost related to expected customer waiting time. The goal is to determine desired capacity/staffing levels that balance the value of timely service with the cost of service capacity.

A rich literature exists in workforce staffing. Several researchers have examined service capacity (labor) scheduling issues in general (Easton and Rossin, 1996; Goodale and Tunc, 1997). Specific examples include staff scheduling at L.L. Bean's call-center (Andrews and Parsons, 1989) and the New Brunswick Telephone Company (Thompson, 1997). However, a gap in the service literature exists between the managerial activity of staff scheduling and the design of sources/infrastructure that provide necessary information. 
Fig. 2 is a presentation of essential elements in the service capacity decision - how to match service staff and customer demand (Pullman et al., 2000). The demand component captures how the service attributes from the supply component affect sales, measured by either increased sales or opportunity cost of lost sales. The level of service attributes reflects the manager's decisions regarding perceived customer preferences, capacity, and operating costs. The economic consequence component accounts for the benefits (revenue or opportunity costs) and costs of the manager's decisions.

The main information need for the demand component is the projected sales based on service product and delivery attributes offered by the supply component. Service customers will trade-off price and other attributes with competitor's attributes (Verma et al., 1999). Customers will come to know of service attributes through recommendations, advertising, observation, and experience. Because of changing customer needs and competitor innovations, service markets are inherently dynamic. Semi-regular analysis of market demand may be sufficient for setting some attributes; however, many service attributes are transient or are changed easily and often, for example, setting expected customer waiting time by scheduling employees at a fast food restaurant located in an airport terminal food court. In this example, unexpected flight changes, flight cancellations, and competitor gaming (promotions) affect expected customer waiting.

The four tasks of labor scheduling (Thompson, 1995) are (1) forecast customer demand; (2) translate demand forecasts into staffing requirements; (3) schedule staff, and (4) real-time control of schedule. First, forecasts must be obtained from the target market. A market utilitybased approach projects market share and imposes the market share proportion on the total population of potential customers. This number of customers serves as the arrival rate to the system and can also determine operations contribution when multiplied by operations contribution per unit. Second, demand forecasts are translated into staff requirements. Inputs of arrival rate and service rate will aid in determining the number of servers (front-line employees) desired using methods from queuing analysis. Third, labor scheduling determines staff schedules. Staff scheduling models are used to assign employees to shifts in order to cover demand in particular time periods. Fourth, real-time control increases or decreases service capacity in order to match supply and demand.

The framework of information needs of market utility-based systems spans various business disciplines. For the purpose of categorizing these information needs, we broke the market utility-based approach down by the four tasks of labor scheduling in Table 1. Each cell represents a focused category of information needs. Each bullet in the cells of the table represents a set of information that must be collected systematically for operational and tactical level decision-making with regard to workforce scheduling.

The various functions of the firm provide primary support for certain categories of these 


\begin{tabular}{|c|c|c|c|}
\hline \multirow[t]{2}{*}{ Labor scheduling task } & \multicolumn{3}{|c|}{ Elements of the market utility-based approach } \\
\hline & Demand component & Supply component & Economic consequence \\
\hline Forecasting demand & $\begin{array}{l}\text { Size of market } \\
\text { Market share as a function of } \\
\text { customer preferences } \\
\text { Arrival rates by time of day }\end{array}$ & & $\begin{array}{l}\text { Operations contribution per } \\
\text { unit before direct server costs }\end{array}$ \\
\hline $\begin{array}{l}\text { Translating forecasts into } \\
\text { staff requirements }\end{array}$ & & $\begin{array}{l}\text { Service rates } \\
\text { Method for finding arrival rate equi- } \\
\text { librium given market share and queu- } \\
\text { ing models (see Goodale et al., 2001) }\end{array}$ & $\begin{array}{l}\text { Variable staffing cost } \\
\text { Fixed costs of } \\
\text { service structure }\end{array}$ \\
\hline Scheduling staff & & $\begin{array}{l}\text { Appropriate staff scheduling model } \\
\text { and solution procedure }\end{array}$ & Total direct server costs \\
\hline Real-time control & $\begin{array}{l}\text { Real-time tracking and within-day } \\
\text { forecasting of customer demand }\end{array}$ & $\begin{array}{l}\text { Resources with real-time flexibil- } \\
\text { ity (employees on-call, cross-trained, } \\
\text { back-room, or remote) }\end{array}$ & $\begin{array}{l}\text { Premium costs for flexible } \\
\text { labor }\end{array}$ \\
\hline
\end{tabular}

Table 1 Information needs of service capacity scheduling

information needs. For example, Management Accounting and Human Resources provide economic parameters for the economic consequence column. Marketing supplies demand forecasting information. Human Resources might supply information on real-time capacity alternatives. Thus, in order to manage service capacity efficiently and effectively, system designs must be multi-disciplinary in order to obtain the necessary information.

The next section explores many important research questions that arise from examining the relationships in Table 1.

\section{Research Questions on Waiting Lines and Workforce Scheduling}

\section{Demand Component}

Which operations attributes have the most affect on demand (for an example, see Verma et al., 1999)? Can we make any generalizations about these attributes? Exploring this issue raises a number of interesting research questions that can only be answered with a multifunctional approach. How we design a market-based approach for forecasting within-day demand in real-time? What is the waiting time elasticity of demand and how can we estimate the parameters of this model? How should congestion-based pricing models be used to manage demand?

\section{Supply Component}

Does a relationship exist between customers' utility for service attributes and the extent of the manager's control of the same attributes? Should managers focus on attributes that may be controllable but provide lower utility for customers, or focus on attributes that are less controllable, but provide higher utility for customers? One manner in which to reflect managers' control is through identification of the process structure (for example, de-coupling back-office activities from the front lines, Metters and Vargas, 2000) that will affect service attributes (for example, quality levels affected by service capacity, Johnston, 1999). One might 
expect to identify trade-offs, and these trade-offs may be viewed differently in the planning phase versus the real-time control phase. For example, sending your front-line service providers home early may not be the best long-term solution to a manager's problem of idle capacity, but it may be the option over which the manager has the most control at that point in time. So with respect to service design, what are the key information and infrastructural processes that supply information for these types of decisions?

\section{Economic Consequence}

In general, what is the relationship between the different types of costs of changing an attribute level and the extent of control the managers' have over the attribute? For example if a manager wishes to improve how responsive customer service representatives (CSRs) are to customer requests, he/she may choose a solution depending on a number of factors. In a knowledge intensive service, the manager may need to educate or train CSRs as part of the new service design. For a service operation where CSRs need smaller skill sets, and who look up information for customers, then improving responsiveness may require investment in a new computer database and/or information network. What are the expected economic returns for these investments (usually provided by the Finance function) and how does the manager's extent of control over the CSRs' performances or information technology factor into these expected returns?

\section{Service Design for Manufacturing}

Driven by increasing global competition, more demanding customers, and new technologies (such as the Internet), many manufacturing firms now proclaim, "We sell solutions." This claim is essentially offering services as a part of the value proposition, where the "solution" includes services intended to add value to customer's use of the tangible product and lower the customer's total life cycle cost.

In fact, many of the most popular topics today are service solutions designed to increase the value added for manufacturing firms, including VMI, early supplier involvement (ESI), mass customization, and supply chain management. VMI is a service offered by many manufacturers and distributors that provides inventory management services for the customer (Andel, 1996; Fry et al., 2000). ESI provides engineering design services for the customer (Dowlatshahi, 2000; Hartley et al., 1997). JIT II focuses on an on-site supplier representative and is essentially the combination of VMI and ESI as implemented at Bose Corporation (Dixon and Porter, 1994). Mass customization is the service of customizing the product after the order for the distributor's, retailer's, or consumer's requirements (Pine, 1993; Pine and Gilmore, 1998; Goldman et al., 1995; Kotha, 1995; Victor and Boynton, 1998). Many supply chain management concepts have to do with providing information and coordination, which is essentially a valueadded service (Handfield et al., 2000; Lee et al., 2000). These are just a few examples of service design for manufacturing in order to add value and lower costs for customers. 
Research in this area clearly requires a multi-disciplinary approach in order to understand the economics of the trade-offs and must draw on theory from micro-economics (agency theory, economies of scope), managerial accounting, marketing, operations, inventory theory, operations research, and information systems. Many issues such as mass customization, supply chain management, and ESI deal with operations-marketing interface issues.

\section{Frameworks for Understanding Service Design for Manufacturing}

Two simple frameworks can be developed for understanding service design for manufacturing. The first of these is based on the timing of the service (pre-sale or after-sale); the second is based on the form of the customer interface.

\section{$\underline{\text { Pre-sales versus After-sales Service }}$}

During the pre-sales phase, manufacturing firms help their customers define the need, design the product, plan the product, and estimate costs. During the after-sales phase, manufacturing firms provide services such as delivering, installing, training, maintaining, repairing, and disposing of the product. Of course, the type of activity depends on the type of product (capital versus consumer goods), the price, and the total contract value. The after-sales service component (sometimes called "field service") is complicated by the fact that the work is often done at the customer's site and requires a highly skills technical person to have good human relations skills (Hill, 1992a, b; Haugen and Hill, 1999).

\section{Inventoried versus Respond-to-order Products}

Make-to-stock (MTS) products have service requirements and metrics quite different from respond-to-order (RTO) products. RTO products include assemble-to-order, make-toorder, engineer-to order, configure-to-order, pack-to-order, and print-to-order products. These products delay some or all of the production process until after the customer has placed the order. MTS products can maintain relatively high utilization due to the fact that they have an inventory to absorb the variability in demand. Service metrics for MTS products include order fill rate, line fill rate, unit fill rate, and perfect order fill rate. Research has been devoted to setting due dates for RTO process such as job shops (Cheng and Gupta, 1989; Markland et al., 1989; Philipoom et al., 1994). These researchers assume that orders can have different promise times based on customer requirements and shop load and that demand is independent of delivery promise time. Other researchers have developed methods for determining a common delivery time for a given set of orders (De et al., 1991, 1992). Because RTO products generally compete on delivery time as well as on customization, RTO processes usually have low utilization. Delivery time is a random variable that can be measured in terms of the mean and variance of delivery time, tardiness, lateness, earliness, on-time delivery percent, and percent shipped complete. On-time performance may be a defined as a function of the customer request date or the firm's promise date and may have a delivery time guarantee (Hill et al., 2000; So and Song, 1998; Ching, 1998). The selection of the best customer interface strategy for a firm involves finding the globally optimal solution, which requires a deep understanding of 
both operations and marketing issues.

\section{Research Questions for Service Design for Manufacturing}

Due Date Promising

How do we design a system for finding the optimal due date to promise to a customer (Spearman and Zhang, 1999)? Should promise times be customized for customers, products, or orders-or not at all? What is the appropriate technology for this order promise mechanism? How can yield management principles be applied to manufacturing? How can we better manage customer delivery expectations (Bitner, 1995)?

\section{Service Guarantees}

What is the optimal guarantee for a manufacturer to offer to a market? What should be guaranteed? When should service guarantees be used primarily as an advertising tool and when should they be used primarily as a tool to set a clear performance standard for the manufacturing firm (Hays et al., 1999; Hays and Hill, 1998, 2001a,b; Wirtz, 1998)? How do product warranties interact with service guarantees (Blischke and Murthy, 1992; Murthy and Blischke, 1992)? This topic should be studied from both marketing and operations perspectives.

\section{Service Recovery and Error Proofing}

How should manufacturers retain customers who have had a service failure (Hays and Hill, 1999; Fornell and Wernerfelt, 1987; Smith et al., 1998)? How can we better learn from our customers when we have a service failure (Hays and Hill, 2001a,b; Rust et al., 1992)? Recently, Stewart and Chase (1999) found that a high percentage of service failures are a result of human error in the delivery process. It would be interesting to conduct a similar analysis to see if this is also true in a manufacturing context.

\section{$\underline{\text { Total System Cost }}$}

What is the best way to model the total system cost and profit? How do we optimize this model? What is the role of service in the total profit function?

\section{Strategy}

What role should service play in a manufacturing firm's strategy? What roles do services play in increasing customer switching costs? (This is essentially what happens with both vendor managed inventory and JIT II.) What is the right balance between services and tangible products?

\section{Service Supply Chain Management}

When should manufacturing firms outsource the services they require and when should they outsource the services they provide to their customers? How should manufacturers structure their contracts, including those for services (Donohue, 2000)? 


\section{e-Commerce}

What is the role of the Internet in providing services-pre-sale product information, customization, after-sale technical help, etc.? How can we use e-commerce configurators to provide a highly automated approach for customers to design/configure highly customized products?

\section{Re-engineering Service Processes}

The previous sections of this paper have advocated multi-disciplinary research in etailing, staffing, and service design for manufacturing. Service process re-engineering, which is used to implement these (and other) service process designs, also requires highly multidisciplinary expertise in areas such as organizational change, psychology, information systems, marketing, and operations. Re-engineering a service process not only demands changes to the service process itself, but also changes to the design of the servicescape, service encounters, training program, recognition and reward program, script dialogues, hiring criteria, etc. A review of the "re-engineering" and "service process design" literatures finds thousands of "how-to" managerial articles and company testimonials, but surprisingly few articles published in academic journals.

\section{Frameworks for Understanding Service Process Re-engineering}

The following service system frameworks provide important foundational concepts for understanding service process re-engineering.

\section{Service Factory, Mass Service, Service Shop, and Professional Service}

The result of this service classification scheme is four service types (quadrants): the Service Factory (low labor Intensity and low consumer contact), the Mass Service (high labor intensity and low customer contact), the Service Shop (low labor intensity and high customer contact), and the Professional Service (high labor intensity and high customer contact). These ideas about service types and associated processes were first defined by Maister and Lovelock (1982) and refined by Schmenner $(1986,1990)$. Silvestro et al. (1992) use the ideas of Maister and Lovelock (1982), and Schmenner $(1986,1990)$, but try to operationalize them by defining six dimensions (i.e. contact time, customization, employee discretion, focus on people or equipment, front and back office, and product versus process characteristics).

\section{Customer-, Co-, and Provider-Routed}

Customer-routed processes are those that offer the customer broad freedom to select from many possible routes through the service delivery system, such as surfing the Internet or going on a Club Med vacation. Co-routed processes offer customers a moderate number of routes through the service delivery system, such as a golf course or trading stocks directly online with a Charles Schwab account. Provider-routed processes constrain customers to follow a very small number of possible routes through the service delivery system, such as using an 
automatic teller machine (ATM) or watching CNN Headline News. In all situations, the customer is allowed to "experience" certain routes through the design of the service delivery system. Collier (1994), Collier and Meyer $(1998,2000)$, and Pine and Gilmore (1998) provide more detailed definitions and insights on this topic.

\section{Research Questions for Service Process Re-engineering}

\section{Primary and Support Processes}

Primary processes are the core processes of the organization that create the core competencies of the firm and satisfy external customers. Support processes do not provide core competencies and usually satisfy only internal customers. For example, a hotel reservation process is a primary process, while supporting processes create the monthly accounting reports or hire new employees. Researchers and managers need to know what percent of total cost is related to the primary versus support processes so they can target improvement initiatives. Sometimes support processes such as human resource management functions are a higher percent of total cost than the primary processes. The Malcolm Baldrige National Quality Award Criteria highlights the importance of focusing on support processes. The idea is to reengineer processes to get the most benefit for the least effort and cost. Are the greatest opportunities for cost improvement in primary or support processes? How does information technology capability change the idea of support services? Collier (1994, pp. 53-60 and 111-131) provides more information on these issues.

\section{$\underline{\text { Positioning Matrix for Services }}$}

How should a positioning matrix for services be defined? Does the service-positioning matrix need to be defined by service industry or can a generic positioning matrix applicable to all services be developed? Hayes and Wheelwright (1979a, b), Silvestro et al. (1992), Kellogg and Nie (1995), Collier and Meyer $(1998,2000)$ help us understand the research questions and the existing knowledge of the relationship between the nature of the service (customer benefit package) and the type of process necessary to create the service.

\section{Process Design and Implementation}

What methods should managers use to find service process capacity bottlenecks? What is the impact of uncertainty (variability) on process performance? What happens to costs when process flow time is radically reduced? What are the advantages and disadvantages of a costreduction strategy versus a time-reduction strategy? When can the work be done in parallel, not sequentially? What frameworks can be used to guide service process re-engineering? Anupindi et al. (1999), Chase (1978), Chase and Stewart (1994), Clausing (1994), Collier (1994), Ramaswamy (1996), and Shostack $(1984,1985)$ are background references on these topics.

\section{Process Improvement Approaches}

What are the characteristics of successful process improvement initiatives such as (a) 
radical re-engineering initiatives (Nolan and Davenport, 1995; Kubeck, 1995); (b) continuous improvement initiatives (Harrington, 1991); and (c) case worker initiatives (Hammer and Champy, 1993)? Under what circumstances should each type of improvement initiatives be adopted? How do you know when to use each improvement approach?

\section{Social Aspects of Service Process Design}

Service processes often include the customer as part of the process (Chase, 1978; Normann, 2001; Pine and Gilmore, 1998; Shostack, 1984, 1985). Human behavior and interaction between the service provider and the customer are critical in service processes with the focus on the "service experience" and the "service encounter activity sequence(s)." A "service encounter activity sequence" consists of all the process steps and associated service encounters necessary to complete a service transaction and fulfill a customer's wants and needs (Collier and Meyer, 1998, p. 1232). Service processes must be safe yet flexible, efficient yet effective, profitable yet entertaining, controlled yet free, objective yet sensitive, high-tech yet soft-touch, produced yet performed, fast yet customer-paced, and standardized yet customized. What is the right balance between these characteristics?

\section{Servicescape Integration into Service Process Design}

A service process and delivery system is more complicated than its goods-producing counterpart. Process outcomes are created through resources such as facilities, information, people, equipment, and networks. The physical setting, or infrastructure, where service encounters take place is termed the "servicescape"(Bitner, 1992, 1993). Servicescapes do more than set the physical operating environment for "acting out" service encounters. Servicescapes also help define the customer's route through the service delivery system and establish the behavioral setting. How should we integrate the role of the servicescape in designing service processes?

\section{Service Process Causal Performance Relationships}

Among the multiple criteria methods, such as analysis of variance, structural equation modeling, simulation, and mathematical programming, which ones are best suited to model and predict service process performance? How can these multiple criteria solutions best be presented to management to enhance management decision-making? Which methods are best suited for quantifying the causal performance relationships? Barker (1994), Baker and Collier (1999), Collier and Wilson (1997), Collier (1991, 1995), Harrington (1991), Li and Collier (2000), Ramaswamy (1996), and Wilson and Collier (2000) are background references on these topics.

\section{Synchronous Networks of Processes versus Individual Optimization of Process and}

\section{Activity Work Sequences}

Understanding the hierarchy of how work gets done and value is created is important for successful improvement initiatives. Today, building entire value chains of multiple processes synchronized into an integrated network represents the highest order way to improve 
organizational performance. For example, Wal-Mart and Honda have developed synchronous networks of processes to maintain their competitive advantage. A synchronous network of processes is the new order winner and performance plateau, and this capability is difficult for competitors to replicate quickly. Should the focus of an organization's improvement initiatives be on individual and independent processes or on building networks of highly coordinated and interdependent processes? How do synchronous networks of processes affect product, process, and organizational time-based performance? Are world-class performing networks the key to competitive advantage in the next round of global competition?

\section{Conclusion}

This paper challenges operations management scholars to devote energy to four service design topics - retail and e-tail service processes, waiting lines and workforce staffing, service design for manufacturing, and re-engineering services. For each topic, the paper presents frameworks, reviews the relevant research, and suggests a number of questions for future research.

Fundamentally, the increased interest in these research topics is driven by new technologies. Scholarly and managerial interest in e-tailing is driven by the explosion of Internet technologies, which will continue to change how service providers interact with customers. Research on workforce scheduling is motivated by the marked increase in the number, variety, and importance of call centers and multi-channel contact centers (including help lines, reservation centers, dispatch centers, etc.). Research in service design for manufacturing is similarly stimulated by new technologies and the rapidly evolving nature of relationships up and down the supply chain. Lastly, research in re-engineering is motivated by the need to implement these and other service design concepts in a world accelerated by technological change.

What emerges from examining these four topics is the multi-disciplinary nature of service design research. Operations management researchers cannot conduct high-quality service design research without recognizing that services involve complex interactions among customers, employees, systems, and products. Service design research must draw on many disciplines in addition to operations management, including marketing, organizational behavior, psychology, corporate strategy, functional strategy, information systems, operations research, and economics. Based on our literature review and our vision for the future, we believe that the service design topics addressed in this paper merit increased research attention in the foreseeable future.

\section{References}

Andel, T., 1996. Manage inventory, own information. Transportation and Distribution 37 (5), 55-58. 
Andersen Consulting, 2000. Who does the best job of e-fulfillment? Logistics Management, 5966.

Andrews, B.H., Parsons, H.L., 1989. L.L. Bean chooses a telephone agent scheduling system. Interfaces 19 (6), 1-9.

Anupindi, R., Chopra, S., Deshmukh, S.D., Mieghem, J.A., Zemel, E., 1999. Managing Business Process Flows, First Edition. Prentice-Hall, Upper Saddle River, NJ.

Baker, T.K., Collier, D.A., 1999. A comparative revenue analysis of hotel yield management heuristics. Decision Sciences 30 (1), 239-263.

Barker T.B., 1994. Quality by Experimental Design. Marcel Dekker, New York, NY.

Bitner, M.J., 1992. Servicescapes: the impact of physical surroundings on customers and employees. Journal of Marketing 56 (2), 57-71.

Bitner, M.J., 1993. Managing the evidence of service. In: Scheuing, E.E., Christopher, W.F. (Eds.), The Service Quality Handbook. American Management Association (AMACOM), New York, NY, pp. 358-370.

Bitner, M.J., 1995. Building service relationships: It is all about promises. Journal of the Academy of Marketing Sciences 23 (4), 246-251.

Blischke, W.R., Murthy, D.N.P., 1992. Product warranty management-l: a taxonomy of warranty policies. European Journal of Operational Research 62 (2), 127-148.

Brynjolfsson, E., Smith, M.D., 2000. Frictionless commerce? A comparison of Internet and conventional retailers. Management Science 46 (4), 563-585.

Call Center Magazine, 2001. www.Callcentermagazine.com/article/CCM20010427S0012, 20 August 2001.

Chase, R.B., 1978. Where does the customer fit in a service operation? Harvard Business Review, 137-142.

Chase, R.B., Stewart, D.M., 1994. Make your service fail-safe. Sloan Management Review 35 (3), 35-45.

Cheng, T.C.E., Gupta, M.C., 1989. Survey of scheduling research involving due date determination decisions. European Journal of Operational Research 38, 156-166.

Ching, W.K., 1998. An inventory model for manufacturing systems with delivery time guarantees. Computers \& Operations Research 25 (5), 367-377.

Clausing, D., 1994. Total Quality Development: A Step-by-Step Guide to World-Class Concurrent Engineering, ASME Press, New York. 
Collier, D.A., 1991. A service quality process map for credit card processing. Decision Sciences $22(2), 406-420$.

Collier, D.A., 1994. The Service/Quality Solution: Using Service Management to Gain Competitive Advantage. Jointly published by Irwin Professional Publishing, Burr Ridge, IL., and American Society of Quality Control's Quality Press, Milwaukee, WI.

Collier, D.A., 1995. Modeling the relationships between process quality errors and overall service process performance.. International Journal of Service Industry Management 6 (4), 4-19.

Collier, D.A., Wilson, D.D., 1997. The role of automation and labor in determining customer satisfaction in a telephone repair service. Decision Sciences 28 (3), 689-708.

Collier, D.A., Meyer, S., 1998. A positioning matrix for services. International Journal of Operations and Production Management 18 (12), 1223-1244.

Collier, D.A., Meyer, S., 2000. An empirical comparison of service matrices. International Journal of Operations and Production Management 20 (5/6), 705-729.

Davis, M.M., 1991. How long should a customer wait for service? Decision Sciences 22 (2), 421434.

Davis, M.M., Maggard, M.J., 1990. An analysis of customer satisfaction with waiting times in a two-stage service process. Journal of Operations Management 9 (3), 324-334.

De, P., Ghosh, J.B., Wells, C.E., 1991. Optimal delivery time quotation and order sequencing. Decision Sciences 22 (2), 379-390.

De, P., Ghosh, J.B.,Wells, C.E., 1992. Optimal due date assignment and sequencing. European Journal of Operational Research 57 (3), 323-331.

Dixon, L., Porter, A.M., 1994. JTT II Revolution in Buying and Selling, Purchasing Magazine. Cahners Publishing Company, Reed Elsevier PLC.

Donohue, K.L., 2000. Efficient supply contracts for fashion goods with forecast updating and two production modes. Management Science 46 (11), 1397-1411.

Dowlatshahi, S., 2000. Designer-buyer-supplier interface: theory versus practice. International Journal of Production Economics 63 (2), 111-130.

Easton, F.F., Rossin, D.F., 1996. A stochastic goal program for employee scheduling. Decision Sciences 27 (3), 541-568.

Evers, P.T., 1995. Expanding the square root law: an analysis of both safety and cycle stocks. The Logistics and Transportation Review 31 (1), 1-20. 
Ferdows, K., De Meyer, A., 1990. Lasting improvements in manufacturing performance: in search of new theory. Journal of Operations Management 9, 168-184.

Fisher, M., Raman, A., McClelland, B., 2000. Rocket science retailing is almost here. Harvard Business Review 78(4), 115-124.

Fitzsimmons, J.A., Fitzsimmons, M.J. (Eds.), 1999. New Service Development: Creating Memorable Experiences, Sage, Thousand Oaks, CA.

Fitzsimmons, J.A., Fitzsimmons, M.J., 2001. Service Management: Operations, Strategy, and Information Technology, 3rd Edition. McGraw-Hill, New York.

Fornell, C., Wernerfelt, B., 1987. Defensive marketing strategy by customer complaint management: a theoretical analysis. Journal of Marketing Research 24 (4), 337-346.

Froehle, C.M., Roth, A.V., Chase, R.B., Voss, C.H., 2000. Strategic determinants of new service development effectiveness: an exploratory examination of strategic operations choices. Journal of Service Research 3 (1), 3-17.

Fry, M.J., Kapuscinski, R., Olsen, T.L., 2000. Coordinating Production and Delivery Under a (z, Z)Type Vendor Managed Inventory Contract, Working Paper. Department of Industrial and Operations Engineering, University of Michigan.

Goldman, S.L., Nagel, R.N., Preiss, K., 1995. Agile Competitors and Virtual Organizations: Strategies for Enriching the Customer. Van Nostrand Reinhold, New York.

Goodale, J.C., Tunc, E., 1997. Tour scheduling with dynamic service rates. International Journal of Service Industry Management 9 (3), 226-247.

Goodale, J.C., Verma, R.V., Pullman, M.E., 2001. A market utility-based model for capacity scheduling in mass services. Production and Operations Management, forthcoming.

Hammer, M., Champy, J., 1993. Re-engineering the Corporation. Harper Business, New York, NY.

Handfield, R.B., Krause, D.R., Scannell, T.V., Monczka, R.M., 2000. Avoid the pitfalls in supplier development. Sloan Management Review 41 (2), 37-49.

Harrington, H.J., 1991. Business Process Improvement. McGraw-Hill, New York, NY.

Hartley, J.L., Zirger, B.J., Kamath, R.R., 1997. Managing the buyer-supplier interface for on-time performance in product development. Journal of Operations Management 15 (1), 5770.

Haugen, D.L., Hill, A.V., 1999. Scheduling to improve field service quality. Decision Sciences 30 (3), 783-804. 
Hays, J.M., Hill, A.V., 1999. The market share impact of service failures. Production and Operations Management 8 (3), 208-220.

Hays, J.M., Hill, A.V., 2001a. A longitudinal study of the effect of a service guarantee on service quality (special issue). Production Operations Management on Quality Management, forthcoming.

Hays, J.M., Hill, A.V., 2001b. An Empirical Investigation of the Relationships between Employee Motivation and Vision, Service Learning, and Perceived Service Quality. Journal of Operations Management, forthcoming.

Hays, J.M., Hill, A.V., Geurs, S.E., 1999. The impact of service guarantees on service quality at Radisson Hotels worldwide. In: Fitzsimmons, J.A., Fitzsimmons, M.J. (Eds.), New Service Development: Creating Memorable Experiences. Sage, Thousand Oaks, CA, pp. 264-276.

Hayes, R.H., Wheelwright, S.C., 1979a. Linking manufacturing process and product life cycles. Harvard Business Review 57 (1), 133-140.

Hayes, R.H., Wheelwright, S.C., 1979b. The dynamics of process-product life cycles. Harvard Business Review 57 (2), 127-136.

Heskett, J.L., Jones, T.O., Loveman, G.W., Sasser Jr, W.E., Schlesinger, L.A., 1994. Putting the service-profit chain to work. Harvard Business Review 72 (2), 164-174.

Hill, A.V., 1992a. An experimental comparison of dispatching rules for field service support. Decision Sciences 23 (1), 235-250.

Hill, A.V., 1992b. Field Service Management: An Integrated Approach to Increasing Customer Satisfaction. Business One Irwin, Homewood, IL.

Hill, A.V., Hays, J.M., Naveh, E., 2000. A model for optimal delivery time guarantees. Journal of Service Research 2 (3), 254-264.

Hoffman, D.L., Novak, T.P., 2000. How to acquire customers on the web. Harvard Business Review 78 (3), 179-188.

Ittig, P.T., 1994. Planning service capacity when demand is sensitive to delay. Decision Sciences 24 (1), 541-559.

Johnston, R., 1999. Service operations management: return to roots. International Journal of Operations and Production Management 19 (2), 104-124.

Kellogg, D.L., Nie, W., 1995. A framework for strategic service management. Journal of Operations Management 13 (4), 323-338.

Kotha, S., 1995. Mass customization: implementing the emerging paradigm for competitive advantage. Strategic Management Journal 16 (special issue), 21-42. 
Kubeck, L.C., 1995. Techniques for Business Process Redesign, Wiley, New York, NY.

Lee, H.L., So, K.C., Tang, C.S., 2000. The value of information sharing in a two-level supply chain. Management Science 46 (5), 622-643.

Li, L., Collier, D.A., 2000. The role of technology and quality on hospital financial performance: an exploratory analysis. International Journal of Service Industry Management 11 (3), 202-224.

Maister, D.H., 1985. The psychology of waiting lines. In: Czepiel, J.A., Solomon, M.R., Surprenant, C.F. (Eds.), The Service Encounter. Lexington Press, Lexington, MA, pp. 113123.

Maister, D., Lovelock, C.H., 1982. Managing facilitator services. Sloan Management Review 23 (4), 19-31.

Markland, R.E., Fry, T.D., Philipoom, P.R., 1989. Due date assignment in a multistage job shop. IIE Transactions 21 (2), 153-162.

Metters, R., Vargas, V., 2000. A typology of de-coupling strategies in mixed services. Journal of Operations Management 18 (6), 663-682.

Murthy, D.N.P., Blischke, W.R., 1992. Product warranty management-II: an integrated framework for study. European Journal of Operational Research 62 (3), 261-281.

Nolan, R.L., Davenport, T., 1995. Re-engineering: Competitive Advantage and Strategic Jeopardy. Harvard Business School, Note \#9-196-016, Boston, Mass.

Normann, R., 2001. Service Management: Strategy and Leadership in Service Business, 3rd Edition. Wiley, New York, NY.

Parasuraman, A.V., Zeithaml, A., Berry, L.L., 1988. SERVQUAL: a multiple-item scale for measuring perceptions of service quality. Journal of Retailing 64 (1), 12-40.

Philipoom, P.R., Rees, L.P., Wiegmann, L., 1994. Using neural networks to determine internallyset due-date. Decision Sciences 25 (5), 825-851.

Pine, II, B.J., 1993. Mass Customization: The New Frontier in Business Competition. Harvard Business School Press, Boston, MA.

Pine, B.J., Gilmore, J.H., 1998. Welcome to the experience economy. Harvard Business Review $76(4), 97-105$.

Pullman, M.E., Goodale, J.C., Verma, R., 2000. Service capacity design with an integrated market utility-based method. In: Fitzsimmons, J.A., Fitzsimmons, M.J. (Eds.), New Service Development: Creating Memorable Experiences. Sage, Thousand Oaks, CA, pp. 111-137. 
Raman, A., 2000. Retail data quality: evidence, causes, costs, and fixes. Technology in Society 22, 97-109.

Ramaswamy, R., 1996. Design and Management of Service Processes: Keeping Customers for Life. Addison-Wesley, Reading, MA.

Roth, A.V., 1996. Competitive progression theory: explanation and empirical evidence. In: Voss, C. (Ed.), Manufacturing Strategy: Operations Strategy in a Global Context. London Business School, London, pp. 309-314.

Roth, A.V., van der Velde, M., 1991. Operations as marketing: a competitive service strategy. Journal of Operations Management 10, 303-329.

Roth, A.V., Jackson Jr, W.E., 1995. Strategic determinants of service quality and performance: evidence from the banking industry. Management Science 41 (11), 1720-1733.

Roth, A.V., Chase, R.B., Voss, C.A., 1997. Service in the US. London Business School, University of North Carolina, University of Southern California Research Monograph, London.

Rust, R.T., Subrarnanian, B., Wells, M., 1992. Making complaints a management tool. Marketing Management 1 (3), 41-45.

Schmenner, R.W., 1986. How can service businesses survive and prosper? Sloan Management Review 27 (3), 21-32.

Schmenner, R.W., 1990. Production/Operations Management, Fourth Edition. Macmillan, New York.

Shostack, G.L., 1984. Designing services that deliver. Harvard Business Review, 133-139.

Shostack, G.L., 1985. Planning the service encounter. In: Czepiel, J.A., Solomon, M.R., Surprenant, C.F. (Eds.), The Service Encounter. Lexington Books, New York, 244 pp.

Silvestro, R., Fitzgerald, L., Johnston, R., Voss, C., 1992. Towards a classification of service processes. International Journal of Service Industry Management 3 (3), 62-75.

Smith, A.K., Bolton, R.N., Wager, J., 1998. A Model of Customer Satisfaction with Service Encounters Involving Failure and Recovery, Marketing Science Institute Working Paper, Report No. 98-100.

So, K.C., Song, J.S., 1998. Price, delivery time guarantees and capacity selection. European Journal of Operational Research 111 (1), 28-49.

Soteriou, A., Zenios, S.A., 1999. Operations, quality and profitability in the provision of banking services. Management Science 45 (9), 1221-1238.

Spearman, M.L., Zhang, R.Q., 1999. Optimal lead time policies. Management Science 45 (2), 290-295. 
Stewart, D.M., Chase, R.B., 1999. The impact of human error on delivering service quality. Production and Operations Management 8 (3), 240-263.

Thompson, G.M., 1995. Labor scheduling using NPV estimates of the marginal benefit of additional labor capacity. Journal of Operations Management 13 (1), 67-86.

Thompson, G.M., 1997. Assigning telephone operators to shifts at New Brunswick Telephone Company. Interfaces 27 (4), 1-11.

Thompson, G.M., 1998. Labor scheduling, part 1. Cornell Hotel and Restaurant Administration Quarterly 39 (5), 22-31.

Verma, R., Boyer, K., 2000. Service classification and management challenges. Journal of Business Strategies 17 (1), 5-24.

Verma, R., Thompson, G.M., Louviere, J.J., 1999. Configuring service operations in accordance with customer needs and preferences. Journal of Service Research 1 (3) 262-274.

Victor, B., Boynton, A.C., 1998. Invented Here: Maximizing Your Organization's Internal Growth and Profitability. Harvard Business School Press, Boston, MA.

Wilson, D.D., Collier, D.A., 2000. Empirical investigation of the Malcolm Baldrige national quality award causal model. Decision Sciences 31 (2), 1-30.

Wirtz, J., 1998. Development of a service guarantee model. Asia Pacific Journal of Management $15(1), 51-75$. 